\title{
Detection of virulence genes and the phylogenetic groups of Escherichia coli isolated from dogs in Brazil
}

\author{
Fernanda Morcatti Coura ${ }^{1}$ Amanda Nadia Diniz ${ }^{1}$ \\ Carlos Augusto Oliveira Junior ${ }^{1}$ Andrey Pereira Lage ${ }^{1}$ Francisco Carlos Faria Lobato $^{1}$ \\ Marcos Bryan Heinemann ${ }^{2}$ Rodrigo Otávio Silveira Silva ${ }^{1}$
}

${ }^{1}$ Escola de Veterinária, Universidade Federal de Minas Gerais (UFMG), Antônio Carlos Avenue, 6627, 31270-901, Belo Horizonte, MG, Brasil. E-mail: rodrigo.otaviosilva@gmail.com. "Corresponding author.

${ }^{2}$ Departamento de Medicina Veterinária Preventiva e Saúde Animal, Faculdade de Medicina Veterinária e Zootecnia, Universidade de São Paulo (USP), São Paulo, SP, Brasil.

\begin{abstract}
This study identified the virulence genes, pathovars, and phylogenetic groups of Escherichia coli strains obtained from the feces of dogs with and without diarrhea. Virulence genes and phylogenetic group identification were studied using polymerase chain reaction. Thirty-seven E. coli isolates were positive for at least one virulence factor gene. Twenty-one (57.8\%) of the positive isolates were isolated from diarrheal feces and sixteen (43.2\%) were from the feces of non-diarrheic dogs. Enteropathogenic E. coli (EPEC) were the most frequently $(62.2 \%)$ detected pathovar in dog feces and were mainly from phylogroup B1 and E. Necrotoxigenic E. coli were detected in $16.2 \%$ of the virulence-positive isolates and these contained the cytotoxic necrotizing factor 1 (cnfl) gene and were classified into phylogroups B2 and D. All E. coli strains were negative for the presence of enterotoxigenic E. coli (ETEC) enterotoxin genes, but four strains were positive for ETECrelated fimbriae $987 P$ and F18. Two isolates were Shiga toxin-producing E. coli strains and contained the toxin genesStx 2 or Stx $2 e$, both from phylogroup B1. Our data showed that EPEC was the most frequent pathovar and B1 and E were the most common phylogroups detected in E. coli isolated from the feces of diarrheic and non-diarrheic dogs.

Key words: dogs, Escherichia coli, pathovars, phylogroups.
\end{abstract}

Deteç̧ão de genes de virulência e grupos filogenéticos de amostras Escherichia coli isoladas de cães no Brasil

RESUMO: Este estudo pesquisou genes de virulência, patovares e grupos filogenéticos de amostras de E. coli isoladas de fezes de cães com e sem diarreia. Os genes de virulência e a identificação de grupos filogenéticos foram estudados pela técnica de reação em cadeia da polimerase (PCR). 37 isolados de E. coli foram positivos para pelo menos um fator de virulência na análise de PCR. Destes, 21 (57,8\%) foram isolados de fezes de cães com diarreia e 16 (43,2\%) de fezes de cães não diarreicos. E. coli enteropatogênica (EPEC) (23/37, 62,2\%) foi o patovar mais frequente detectado em fezes de cães e foram classificados principalmente como filogrupos B1 e E. E. coli necrotoxigênica (NTEC) positivos para CNF1 foram detectados $(6 / 37,16,2 \%)$ e classificados como B2 e D. Todas as amostras de E. coli foram negativas quanto à presença de genes de enterotoxinas de E. coli enterotoxigênica (ETEC), mas quatro amostras foram positivas para fimbrias relacionadas ao ETEC, $987 P$ (2) e F18 (2). As amostras de E. coli (STEC) produtora de toxina Shiga foram positivas para a toxina Stx2 (1/37) e Stx2e (1/37), ambas do filogrupo B1. Nossos resultados indicaram que EPEC foi o patovar mais frequente e B1 e E foram os filogrupos mais comuns detectados em amostras E. coli isoladas de fezes de cães diarreicos e não diarreicos.

Palavras-chave: cães, Escherichia coli, filogrupos, patovares.

\section{INTRODUCTION}

Escherichia coli are a component of normal intestinal microbiota in humans and other animals. Phenotypic and genotypic characteristics allow the identification of $E$. coli pathogenic strains or pathovars (COURA et al., 2014). Dogs are colonized by $E$. coli during the first days of their life and some strains can cause enteric or extra-intestinal infections (BEUTIN, 1999).

Diarrheagenic E. coli strains are classified as pathotypes or pathovars according to their virulence 
factors, pathogenesis, and clinical signs or symptoms present in the host. It is believed that different pathovars can cause diarrhea in dogs. These included enteropathogenic E. coli (EPEC), enterotoxigenic $E$. coli (ETEC), enterohemorrhagic E. coli (EHEC), Shiga toxin-producing $E$. coli (STEC), and necrotoxigenic E. coli (NTEC) (BEUTIN, 1999). Other pathovars are associated with diarrhea in other animals, namely enteroaggregative $E$. coli (EAEC) and enteroinvasive E. coli (EIEC) (MAINIL, 2013). Because of the close contact with humans, dogs could increase the risk of transmitting potentially zoonotic microorganisms, such as EPEC and STEC (BEUTIN, 1999).

In addition to the pathotype and pathovar classification, E. coli strains can be assigned to one of the seven phylogenetic groups, including A, B1, B2, C, D, E, and F (CLERMONT et al., 2013). E. coli genomic structure has shown that the strains belonging to different phylogroups are associated with the disease state and source of isolation (CLERMONT et al., 2013). The extraintestinal pathogenic E. coli (ExPEC) strains are clustered mostly in groups B2 and $\mathrm{D}$ and intestinal pathogenic $E$. coli are mostly in phylogroups A, B1, and E (ESCOBAR-PÁRAMO et al., 2004; CLERMONT et al., 2011). Although phylogenetic characterization is an important tool to improve the understanding of $E$. coli populations and the relationship between strains and disease (CLERMONT et al., 2011; COURA et al., 2015), few studies have determined phylogenetic groups of $E$. coli isolated from dogs worldwide, and of those that did, the most frequently used method was a triplex PCR method developed by CLERMONT in 2000. This method is only capable of determining phylogroups A, B1, B2, and D (HARADA et al., 2012; SALVARANI et al., 2012; SCHMIDT et al., 2015) instead of the seven phylogroups that were detected in this study. In Brazil, only two studies identified E. coli pathovars associated with diarrhea in dogs (ALMEIDA et al., 2012; PUÑO-SARMIENTO et al., 2013), but none determined the phylogenetic groups of E. coli. Therefore, this study aimed to detect the virulence genes, pathovars, and phylogenetic groups of $E$. coli strains isolated from the feces of dogs with and without diarrhea.

\section{MATERIALS AND METHODS}

\section{Stool samples}

Stool samples were collected from 154 dogs, of which 92 were diarrheic and 62 were without diarrhea. Samples from diarrheic dogs were obtained directly from the rectum, at the Veterinary Hospital of
Universidade Federal de Minas Gerais (Belo Horizonte city), upon admission. Collections were performed from dogs that were undergoing a consultation for the occurrence of diarrhea. With owner's consent, fecal samples from non-diarrheic animals were obtained from the dogs of students attending the Universidade Federal de Minas Gerais. For non-diarrheic dogs, fecal samples were either taken directly from the rectum or after spontaneous defecation, sampling the upper portion of the fecal content that did not have contact with the environment.

\section{E. coli isolation and DNA extraction}

Fecal samples were directly plated onto MacConkey agar and incubated for 18 to $24 \mathrm{~h}$ at $37^{\circ} \mathrm{C}$. At least one colony with the characteristics of $E$. coli (lactose-fermenting colonies) per animal were selected for molecular analysis. Suggestive colonies were screened for the uidA gene to confirm the presence of E. coli (MCDANIELS et al., 1996). Bacterial DNA was obtained by suspending the colonies in $50 \mu \mathrm{L}$ of sterile water and heating at $100^{\circ} \mathrm{C}$ for $10 \mathrm{~min}$ in a thermoblock.

\section{Detection of virulence genes and characterization of phylogenetic groups \\ The presence of virulence genes was} determined by PCR. Strains were screened for the following genes: the transcriptional regulator aggR (TOKUDA et al., 2010); cnf1 and cnf2 (BLANCO etal., 1996); the toxin genes sta, Stx1, Stx2 (multiplex PCR) (FRANCK et al., 1998); intimin (eae) (BLANCO et al., 2006); bundle-forming pili (bfpA) (GUNZBURG; TORNIEPORTH; RILEY, 1995); ipaH for EIEC (ARANDA et al., 2007); Stx2e, the most frequent pathovar identified, F41, stb, LT, 987P, F18, K88, and K99 (multiplex PCR) (MACÊDO et al., 2007). The PCR reaction conditions were performed according to each author, with no modifications. The following $E$. coli reference strains were used as positive controls: The O157:H7 strain EDL 933 (eaeA, Stx1, Stx2, ehxA, iha, toxB, efa1), EAEC O42 (astA, aggR, aaf, pet), S5 (F17,cnf2), E2348/69 (bfpA, eae), 2568 (stb, STaP, F18, Stx2e), 2569 (stb, LT, K88), 2570 (987P, StaP), and CNF1 strain 2571 (StaP, K99, F41). Sterile water was used as a negative control. Amplified DNA was resolved on a $1.5 \%$ agarose gel, stained with $0.5 \mu \mathrm{g} /$ $\mathrm{mL}$ of ethidium bromide, and photographed under UV light. A 100bp DNA size marker (100bp DNA ladder, New England Biolabs, USA) was used to estimate the size of the amplified product.

$$
\text { E. coli strains positive for one or }
$$
more virulence genes were tested by PCR for 
characterization of the phylogenetic groups $\mathrm{A}, \mathrm{B} 1$, $\mathrm{B} 2, \mathrm{C}, \mathrm{D}, \mathrm{E}$, and F, according to CLERMONT et al. (2013). If a phylogenetic group was not identified, then the E. coli strains were classified as unknown.

\section{Statistical analysis}

Categorical variables were examined using a chi-square test or Fisher's exact test. For the variable age, the Mann-Whitney U or KruskalWallis test was used.

\section{RESULTS AND DISCUSSION}

Out of 154 stool samples tested, 37 (24\%) were positive for $E$. coli isolates, with at least one virulence gene detected in PCR analysis. Of these positive isolates, $21(57.8 \%)$ were obtained from dogs with diarrhea and 16 (43.2\%) were obtained from non-diarrheic dogs. Statistical analysis showed no association between pathovars and diarrhea or age. Table 1 shows the distribution of strains, according to the pathovar and its correlation with virulence genes. The distribution of phylogenetic groups among the pathogenic $E$. coli is shown in table 2 .

In our study, EPEC was the most frequent pathovar detected and accounted for $62.1 \%$ of the PCR-positive strains. This pathovar was isolated from $14.9 \%$ of the dogs, and the frequency was higher in diarrhea samples than in those from apparently healthy animals. EPEC is characterized by the production of intimin (eae) and it can be classified as typical or atypical based on the presence or absence of bundle-forming pili (bfp), respectively (MAINIL, 2013). Our results are in accordance with other studies and suggested that EPEC are important diarrheagenic $E$. coli in dogs, especially atypical EPEC (NAKAZATO et al., 2004; ALMEIDA et al.,
2012; PUÑO-SARMIENTO et al., 2013). In addition, EPEC were mainly classified in phylogroups B1 and $\mathrm{E}$, as reported in previously published studies in zoo animals, dogs, pigs, and calves (BALDY-CHUDZIK et al., 2008; TRAMUTA et al., 2008; COURA et al., 2017). Moreover, intestinal associated E. coli are mainly in phylogroups B1 and E (CLERMONT et al., 2011). These findings are important since EPEC was detected more frequently in diarrheic dogs than in non-diarrheic dogs. The EPEC can complicate the clinical signs of diarrhea and should be considered as a possible differential diagnosis in dogs with enteric infections (KJAERGAARD et al., 2016).

In the present study, seven dogs $(4.5 \%)$ were positive for strains containing cnfl, including one hybrid strain with eae and cnfl. In dogs, CNF1 is the most frequent toxin of NTEC detected from dogs (BEUTIN, 1999). Moreover, in our study, cnf1 strains were usually classified in phylogroups B2 and D (Table 2). In previous studies, it was shown that ExPEC strains are clustered mostly in groups B2 and D (ESCOBAR-PÁRAMO et al., 2004). Interestingly, $E$. coli strains isolated from septicemic human patients belonged mainly to groups $\mathrm{B} 2$ and $\mathrm{D}$ (ČUROVÁ et al., 2014). Furthermore, cnfl strains in phylogroup B2 were associated with diarrhea and mortality of puppies (TURCHETTO et al., 2015) and phylogroup B2 was associated with urine samples that were positive for cnfl (OSUGUI et al., 2014). Collectively, these results suggested that NTEC from dogs possess ExPEC characteristics.

All E. coli strains isolated and tested by PCR were negative for the presence of heat labile and heat stable enterotoxins genes. Two isolates were positive for fimbriae genes, including 987P (F6) and F18, and both are generally related to ETEC strains of animal origin (MAINIL, 2013). Other studies did

Table 1 - Distribution of pathovars and virulence factors of Escherichia coli isolated from non-diarrheic and diarrheic dogs (n=37).

\begin{tabular}{|c|c|c|c|}
\hline \multirow[t]{2}{*}{ Pathovars (virulence factors) } & \multicolumn{3}{|c|}{ - } \\
\hline & Non-diarrheic & Diarrheic & Total \\
\hline HYBRID $(e a e, s t a)$ & $0(0)$ & $1(2.7)$ & $1(2.7)$ \\
\hline NTEC $(c n f l)$ & $3(8.1)$ & $3(8.1)$ & $6(16.2)$ \\
\hline HYBRID (eaeand $c n f I$ ) & $1(2.7)$ & $0(0)$ & $1(2.7)$ \\
\hline Atypical EPEC (eae) & $9(24.3)$ & $13(35.1)$ & $22(59.4)$ \\
\hline Typical EPEC (eae, $b f p)$ & $1(2.7)$ & $0(0)$ & $1(2.7)$ \\
\hline 987P fimbria & $1(2.7)$ & $1(2.7)$ & $2(5.4)$ \\
\hline F18 fimbria & $0(0)$ & $2(5.4)$ & $2(5.4)$ \\
\hline STEC $($ Stx $2 e)$ & $0(0)$ & $1(2.7)$ & $1(2.7)$ \\
\hline STEC (Stx2) & $1(2.7)$ & $0(0)$ & $1(2.7)$ \\
\hline
\end{tabular}

Ciência Rural, v.48, n.2, 2018. 
Table 2 - Distribution of phylogenetic groups and virulence factor genes of Escherichia coli obtained from the feces of dogs ( $\mathrm{n}=37$ ).

\begin{tabular}{|c|c|c|c|c|c|c|}
\hline \multirow[t]{2}{*}{ Virulence } & \multirow[b]{2}{*}{ A } & \multirow{2}{*}{ B1 } & \multicolumn{2}{|c|}{-----Phylogroun $(\%)-$} & ----------. & ------------------- \\
\hline & & & B2 & $\mathrm{D}$ & $\mathrm{E}$ & Unknown \\
\hline $987 P$ & $0(0)$ & $2(5.4)$ & $0(0)$ & $0(0)$ & $0(0)$ & $0(0)$ \\
\hline eae/sta & $0(0)$ & $0(0)$ & $0(0)$ & $0(0)$ & $0(0)$ & $1(2.7)$ \\
\hline cnfl & $0(0)$ & $0(0)$ & $4(10.8)$ & $1(2.7)$ & $0(0)$ & $1(2.7)$ \\
\hline eae/cnfl & $0(0)$ & $0(0)$ & $0(0)$ & $0(0)$ & $1(2.7)$ & $0(0)$ \\
\hline eae & $1(2.7)$ & $4(10.8)$ & $3(8.1)$ & $1(2.7)$ & 7 (18.9) & $6(16.2)$ \\
\hline$e a e / b f p$ & $0(0)$ & $0(0)$ & $0(0)$ & $1(2.7)$ & $0(0)$ & $0(0)$ \\
\hline$F 18$ & $0(0)$ & $0(0)$ & $0(0)$ & $0(0)$ & $0(0)$ & $2(5.4)$ \\
\hline Stx $2 e$ & $0(0)$ & $1(2.7)$ & $0(0)$ & $0(0)$ & $0(0)$ & $0(0)$ \\
\hline Stx 2 & $0(0)$ & $1(2.7)$ & $0(0)$ & $0(0)$ & $0(0)$ & $0(0)$ \\
\hline Total & $1(2.7)$ & $8(21.6)$ & $7(18.9)$ & $3(8.1)$ & $8(21.6)$ & $10(27)$ \\
\hline
\end{tabular}

not find enterotoxins in E. coli obtained from dogs (HAMMERMUELLER et al., 1995; NAKAZATO et al., 2004; PUÑO-SARMIENTO et al., 2013). Fimbriae F18 and 987P are commonly reported in ETEC isolated from piglets (MACÊDO et al., 2007), but their importance as adherence fimbriae for $E$. coli isolated from dogs should be further investigated. Our results from fimbrial-positive strains are difficult to compare to other studies since only two isolates were positive and both were negative for the toxin STa. It is also important to note that, according to the owners, both dogs positive for 987P and F18 were housed without contact with other animals.

Two STEC strains were detected. One was positive for toxin Stx2 and another was positive for Stx2e, with both strains from phylogroup B1. The STEC from dogs are usually positive for Stx2 (HAMMERMUELLER et al., 1995). Regarding the phylogenetic group, STEC strains of phylogroup B1 were also detected in calves (COURA et al., 2017). Because of the low number of STEC isolates, the importance of this pathovar in dogs and its phylogenetic group placement is difficult to assess.

Two E. coli strains identified during this investigation could not be classified into a phylogenetic group, both containing the eae gene. This finding emphasized the dynamics of gene transfer between $E$. coli strains of different pathovars, resulting in the development of new pathovars and contributing to the emergence of pathogenic strains (MÜLLER et al., 2007), such as E. coli O104:H4.

E. coli characterized by PCR for virulence genes obtained from the feces of dogs were mostly from phylogroups B1 and E. This finding reinforces the possible connection between $E$. coli strains and diarrhea in dogs, since intestinal pathogenic E. coli are mostly B1 and E (CLERMONT et al., 2011) and the virulence genes identified are associated with diarrhea in humans and other animals (MAINIL, 2013; COURA et al., 2014; COURA et al., 2017).

Some of the E. coli strains detected in this study could not be classified into phylogroups using the Clermont method. This occasionally occurs because it uses a combination of the presence and absence of certain genes. According to CLERMONT et al. (2013), some $E$. coli strains cannot be assigned to a phylogroup due to the extremely rare occurrence of the phylogroup, the strain is the result of large-scale recombination between two different phylogroups, or the highly variable $E$. coli genome content was driven by the gain and loss of genes.

This study provided important information regarding pathogenic $E$. coli isolated from the feces of dogs. The presence of virulence genes and the phylogenetic classification of $E$. coli were determined and are important in understanding canine E. coli infections and associated syndromes. There was no association between virulence genes or phylogroups and any of the study's epidemiological aspects, including age, breed, or gender. Our results indicated that EPEC were the most frequently identified pathovar in the feces of dogs and are mainly classified into the intestinal origin phylogroups, B1 and E. NTEC positive for cnfl were also identified and were mostly in phylogroups B2 and D, which are associated with ExPEC. Detection of other pathovars was very low, but the ones identified were associated with disease in humans and other animal species. Because of the close contact between dogs and humans and the likely contact with other animal species, these results emphasized the need for further studies to clarify the role of E. coli in dogs. 


\section{ACKNOWLEDGMENTS}

This research was supported by funds from Fundação de Amparo à Pesquisa do Estado de Minas Gerais (FAPEMIG), Coordenação de Aperfeiçoamento de Pessoal de Nível Superior (CAPES) (Process n $\left.{ }^{\circ} 23038.004886 / 2015-23\right)$, Conselho Nacional de Desenvolvimento Científico e Tecnológico (CNPq, INCT, and PRPq-UFMG). APL and FCFL are indebted to CNPq for their fellowships. APL is also supported by the Programa Pesquisador Mineiro (PPM - FAPEMIG)

\section{BIOETHICS \\ AND COMMITTEE APPROVAL}

\section{BIOSSECURITY}

All animal procedures were approved by the Comite de Ética em Experimentação Animal (CEUA/UFMG), protocol $51 / 2015$.

\section{CONFLICT OF INTEREST}

The authors declare that they have no conflicts of interest.

\section{REFERENCES}

ALMEIDA, P. M. P. DE et al. Characterization of atypical Enteropathogenic Escherichia coli (aEPEC) isolated from dogs. Veterinary Microbiology, v. 158, p. 420-424, 2012. Available from: <https://doi.org/10.1016/j.vetmic.2012.02.021>. Accessed: July 11, 2017. doi: 10.1016/j.vetmic.2012.02.021.

ARANDA, K. R. S. et al. Single multiplex assay to identify simultaneously enteropathogenic, enteroaggregative, enterotoxigenic, enteroinvasive and Shiga toxin-producing Escherichia coli strains in Brazilian children. FEMS Microbiology Letters, v. 267, n. 2, p. 145-150, 2007. Available from: <http://onlinelibrary.wiley.com/doi/10.1111/ j.1574-6968.2006.00580.x/abstract; jsessionid=95F 88DA82 993AC095730E0049F3F7396.f04t04>. Accessed: July 11, 2017. doi: 10.1111/j.1574-6968.2006.00580.x.

BALDY-CHUDZIK, K. et al. Phylogenetic background, virulence gene profiles, and genomic diversity in commensal Escherichia coli isolated from ten mammal species living in one zoo. Veterinary Microbiology, v. 131, n. 1-2, p. 173-184, 2008. Available from: $<$ https://doi.org/10.1016/j.vetmic.2008.02.019>. Accessed: July 11, 2017. doi: 10.1016/j.vetmic.2008.02.019.

BEUTIN, L. Escherichia coli as a pathogen in dogs and cats. Veterinary Research, v. 30, p. 285-298, 1999. Available from: $<$ https://hal.archives-ouvertes.fr/hal-00902570/document $>$. Accessed: July 11, 2017.

BLANCO, M. et al. Polymerase chain reaction for detection Escherichia coli strains producing cytotoxic necrotizing factor type 1 and type 2 (CNF1 and CNF2). Journal of microbiological methods, v. 26, p. 95-101, 1996. Available from: <https://doi. org/10.1016/0167-7012(96)00900-1>. Accessed: July 11, 2017. doi: 10.1016/0167-7012(96)00900-1.

BLANCO, M. et al. Identification of two new intimin types in atypical enteropathogenic Escherichia coli. International Microbiology, v. 9, p. 103-110, 2006. Available from: <http:/www.im.microbios. org/0902/0902103.pdf>. Accessed: July 11, 2017.
CLERMONT, O. et al. The Clermont Escherichia coli phylo-typing method revisited: improvement of specificity and detection of new phylo-groups. Environmental microbiology reports, v. 5, n. 1, p. 58-65, fev. 2013. Available from: <http://onlinelibrary.wiley.com/ doi/10.1111/1758-2229.12019/abstract>. Accessed: July 11, 2017. doi: $10.1111 / 1758-2229.12019$.

CLERMONT, O. et al. Animal and human pathogenic Escherichia coli strains share common genetic backgrounds. Infection, genetics and evolution, v. 11, n. 3, p. 654-62, abr. 2011. Available from: <https://doi.org/10.1016/j.meegid.2011.02.005>. Accessed: July 11, 2017. doi: 10.1016/j.meegid.2011.02.005.

COURA, F. M. et al. Characterization of virulence factors and phylogenetic group determination of Escherichia coli isolated from diarrheic and non-diarrheic calves from Brazil. Folia Microbiologica, v. 62, n. 2, p. 139-144, 2017. Available from: <https://link.springer.com/article/10.1007\%2 Fs12223-016-0480-9>. Accessed: July 11, 2017. doi: 10.1007/ s12223-016-0480-9.

COURA, F. M. et al. Phylogenetic group determination of Escherichia coli Isolated from Animals Samples. The scientific world, v. 2015, p. 1-4, 2015. Available from: <https://www. hindawi.com/journals/tswj/2015/258424/>. Accessed: July 11, 2017. doi: $10.1155 / 2015 / 258424$.

COURA et al. Patotipos de Escherichia coli causadores de diarreia em bezerros: uma atualização. Pesquisa Veterinaria Brasileira, v. 34, n. 9, p. 811-818, 2014. Available from: <http://www.scielo. br/pdf/pvb/v34n9/v34n9a01.pdf >. Accessed: July 11, 2017. doi: 10.1590/S0100-736X2014000900001.

ČUROVÁ, K.; KMEŤOVÁ, M.; VARGOVÁ, R.; LOVAYOVÁ, V.; SIEGFRIED, L. Toxins of Extraintestinal Escherichia coli Isolated from Blood Culture. Clinical Microbiology, v. 3, n. 5, p. 5-8, 2014. Available from: $<$ https://www.omicsonline.org/openaccess/toxins-of-extraintestinal-escherichia-coli-isolated-fromblood-culture-2327-5073.1000171.pdf>. Accessed: July 11, 2017. doi: $10.4172 / 2327-5073.1000171$.

ESCOBAR-PÁRAMO, P. et al. A specific genetic background is required for acquisition and expression of virulence factors in Escherichia coli. Molecular Biology and Evolution, v. 21, n. 6, p. 1085-1094, 2004. Available from: <https://oup.silverchair-cdn. com/oup/backfile/Content_public/Journal/mbe/21/6/10.1093 molbev_msh118/1/msh118>. Accessed: July 11, 2017. doi: $10.1093 / \mathrm{molbev} / \mathrm{msh} 118$.

FRANCK, S. M. et al. Multiplex PCR for enterotoxigenic, attaching and effacing, and Shiga toxin-producing Escherichia coli strains from calves. Journal of clinical microbiology, v. 36, n. 6, p. 1795-7, jun. 1998. Available from: <http://jcm.asm.org/ content/36/6/1795.full.pdf+html $>$. Accessed: July 11, 2017.

GUNZBURG, S. T. et al. Identification of enteropathogenic Escherichia coli by PCR-based detection of the bundle-forming pilus gene. Journal of Clinical Microbiology, v. 33, n. 5, p. 13751377, 1995. Available from: < https://www.ncbi.nlm.nih.gov/pmc/ articles/PMC228170/pdf/331375.pdf>. Accessed: July 11, 2017.

HAMMERMUELLER, J. et al. Detection of toxin genes in Escherichia coli isolated from normal dogs and dogs with diarrhea. Canadian Journal of Veterinary Research, p. 265-270, 1995. Available from: <https://www.ncbi.nlm.nih. 
gov/pmc/articles/PMC1263780/pdf/cjvetres00028-0027.pdf>. Accessed: July 11, 2017.

HARADA, K. et al. Antimicrobial resistance, virulence profiles, and phylogenetic groups of fecal Escherichia coli isolates: A comparative analysis between dogs and their owners in Japan. Comparative Immunology, Microbiology and Infectious Diseases, v. 35, n. 2, p. 139 144,2012. Available from: <https://doi.org/10.1016/j.cimid.2011.12.005>. Accessed: July 11, 2017. doi: 10.1016/j.cimid.2011.12.005.

KJAERGAARD, A. B. et al. Enteropathogenic Escherichia coli (EPEC) infection in association with acute gastroenteritis in $7 \mathrm{dogs}$ from Saskatchewan. Canadian Veterinary Journal, v. 57, 2016 Available from: <https://www.ncbi.nlm.nih.gov/pmc/articles/ PMC4982568/pdf/cvj_09_964.pdf>. Accessed: July 11, 2017.

MACÊDO, N. R. et al. Detection of pathogenic strains by multiplex PCR and antimicrobial sensitivity of Escherichia coli isolated from piglets. Arquivos Brasileiros de Medicina Veterinária e Zootecnia, v. 59, n. 5, p. 1117-1123, 2007. Available from: <http://www.scielo.br/scielo.php?script=sci_artt ext\&pid=S0102-09352007000500005>. Accessed: July 11, 2017. doi: $10.1590 / \mathrm{S} 0102-09352007000500005$

MAINIL, J. Escherichia coli virulence factors. Veterinary immunology and immunopathology, v. 152 , n. 1-2, p. 2-12, 15 mar. 2013. Available from: <https://doi.org/10.1016/j. vetimm.2012.09.032>. Accessed: July 11, 2017. doi: 10.1016/j. vetimm.2012.09.032.

MCDANIELS, A. E. et al. Confirmational identification of Escherichia coli, a comparison of genotypic and phenotypic assays for glutamate decarboxylase and $\beta$-D-Glucuronidase. Applied and Environmental Microbiology, v. 62, n. 9, p. 3350-3354, 1996. Available from: <https://www.ncbi.nlm.nih.gov/pmc/articles/ PMC168131/>. Accessed: July 11, 2017.

MÜLLER, D. et al. Identification of unconventional intestinal pathogenic Escherichia coli isolates expressing intermediate virulence factor profiles by using a novel single-step multiplex PCR. Applied and Environmental Microbiology, v. 73, n. 10, p. 3380-3390, 2007. Available from: <https:// www.ncbi.nlm.nih.gov/pmc/articles/PMC1907121/>. Accessed: July 11, 2017. doi: 10.1128/AEM.02855-06.

NAKAZATO, G. et al. Attaching and effacing Escherichia coli isolated from dogs in Brazil: characteristics and serotypic relationship to human enteropathogenic E. coli (EPEC). Veterinary Microbiology, v. 101, p. 269-277, 2004. Available from: <https:// www.ncbi.nlm.nih.gov/m/pubmed/15262000/>. Accessed: July 11, 2017. doi: 10.1016/j.vetmic.2004.04.009.
OSUGUI, L. et al. Virulence genotypes, antibiotic resistance and the phylogenetic background of extraintestinal pathogenic Escherichia coli isolated from urinary tract infections of dogs and cats in Brazil. Veterinary Microbiology, v. 171, n. 1-2, p. 242-247, 2014. Available from: <https://doi.org/10.1016/j. vetmic.2014.03.027>. Accessed: July 11, 2017. doi: 10.1016/j. vetmic.2014.03.027.

PUÑO-SARMIENTO, J. et al. Detection of diarrheagenic Escherichia coli strains isolated from dogs and cats in Brazil. v. 166, p. 676-680, 2013. Available from: <https://doi.org/10.1016/j. vetmic.2013.07.007>. Accessed: July 11, 2017. doi: 10.1016/j. vetmic.2013.07.007.

SALVARANI, S. et al. Occurrence and functionality of cycle inhibiting factor, cytotoxic necrotising factors and cytolethal distending toxins in Escherichia coli isolated from calves and dogs in Italy. Research in veterinary science, v. 92, n. 3, p. 372-7, jun. 2012. Available from: <https://doi.org/10.1016/j. rvsc.2011.04.019>. Accessed: July 11, 2017. doi: 10.1016/j. rvsc.2011.04.019.

SCHMIDT, V. M. et al. Antimicrobial resistance risk factors and characterisation of faecal $E$. coli isolated from healthy Labrador retrievers in the United Kingdom. Preventive Veterinary Medicine, v. 119, n. 1-2, p. 31-40, 2015. Available from: <https:// doi.org/10.1016/j.prevetmed.2015.01.013>. Accessed: July 11, 2017. doi: 10.1016/j.prevetmed.2015.01.013.

TOKUDA, K. et al. Characterization of typical and atypical enteroaggregative Escherichia coli in kagoshima, Japan: Biofilm formation and acid resistance. Microbiology and Immunology, v. 54, n. 6, p. 320-329, 2010. Available from: $<$ http://onlinelibrary.wiley.com/doi/10.1111/j.13480421.2010.00210.x/abstract>. Accessed: July 11, 2017. doi: 10.1111/j.1348-0421.2010.00210.x.

TRAMUTA, C. et al. Phylogenetic background of attaching and effacing Escherichia coli isolates from animals. Veterinary Research Communications, v. 32, n. 6, p. 433-437, 2008. Available from: <https://link.springer.com/article/10.1007\%2 Fs11259-008-9042-1>. Accessed: July 11, 2017. doi: 10.1007/ s11259-008-9042-1.

TURCHETTO, S. et al. Phenotypic features and phylogenetic background of extraintestinal hemolytic Escherichia coli responsible of mortality in puppies. Veterinary Microbiology, v. 179, n. $1-2$, p. $126-130,2015$. Available from: $<$ https://doi. org/10.1016/j.vetmic.2015.03.004>. Accessed: July 11, 2017. doi: 10.1016/j.vetmic.2015.03.004 